\title{
Cultural and Language Identity of the Thesaban Takbai Malay Ethnic, Southern Thailand: A Phenomenological Analysis
}

Novel Lyndon ${ }^{1}$

Hasni Zakaria²

Azima A.M ${ }^{3}$

Rosniza Aznie C. $\mathbf{R}^{4}$

Sarmila M.S 5

\author{
${ }^{1}$ Associate Professor, Faculty of Social Sciences and Humanities, Universiti Kebangsaan Malaysia \\ novel@ukm.edu.my \\ ${ }^{2}$ Research Officer, Faculty of Social Sciences and Humanities, Universiti Kebangsaan Malaysia \\ hasnizakaria@ymail.com \\ ${ }^{2}$ Associate Professor, Faculty of Social Sciences and Humanities, Universiti Kebangsaan Malaysia \\ azima@ukm.edu.my \\ ${ }^{4}$ Senior Lecturer, Faculty of Social Sciences and Humanities, Universiti Kebangsaan Malaysia \\ aznie@ukm.edu.my \\ ${ }^{5}$ Senior Lecturer, Faculty of Social Sciences and Humanities, Universiti Kebangsaan Malaysia \\ sarmila@ukm.edu.my
}

\section{Doi:10.5901/mjss.2015.v6n4s3p11}

\section{Abstract}

The constructions of ethnic minority group identity are often overshadowed by the majority group. The main objective of this study is to understand the nature of language and cultural identity desired by the ethnic minority group. This study used the phenomenological research paradigm that focuses on understanding the Malay ethnic group of Southern Thailand in Thesaban Takbai, Narathiwat in respect of the formation of ethnic identity base on their world-view. The unit of analysis in this study consists of ten Malay ethnic individuals of Southern Thailand living in Thesaban Takbai, Narathiwat, Thailand. Ten informants consisting of five men and five women with the age ranging from 20 to 60 years old were selected based on the type of occupations and level of education to be interviewed in-depth in this study. The sample was selected using the non-probability sampling that is the purposive and snowball sampling. The findings show that the Malay ethnic of Thesaban Takbai in Southern Thailand still desire to maintain the Patani Malay culture in terms of clothing and name. The informants' views towards the language identity show that they are very tolerant of the position of Thai Language as the National Language. The implications of this study is that the Thai government should take into consideration the interests of the minority groups and not to practice the integration policy in the form of top-down administrative through the assimilation approach that is considered as discriminating to the minority groups.

Keywords: Malay Ethnic, Southern Thailand, identity, Patani Malays, culture, phenomenology

\section{Introduction}

Based on the previous studies by Che Mohd Aziz (2012), Aphornsuvan (2004), Dorairajoo (2009), Imtiyaz (2009) and Suwannathat-Pian (2002) show that the question of identity is a very sensitive issue and cause problems that could trigger prolonged conflict like the one happening between the Southern Thailand Malay ethnic with the Government of Thailand. Why the question of identity has become a very sensitive issue? The answer is closely related to the importance of identity from the perspectives of sense of belonging as well as a symbol of survival to the community. In an inclusive identity, the elements highlighting the unique characteristic that distinguishes one group from another. These elements include religion, language, clothing, food, values, norms, and others. Therefore, there are certain minority groups rise to oppose the identity integration policies by the majority group as happened in South Thailand.

When discussing about the construction of identity based on the minority and majority conflict, the focus is more often given to the aspect of policy planning or implementation by the majority that is the government. This can be seen in 
the identity issue involving the Malay ethnic minority in Southern Thailand. In this issue, the majority that is the Government of Thailand is more likely to be criticized as a party that is inconsiderate of the interests of the minority groups and ethnocentric in implementing the top-down administrative integration policy through the assimilation approaches that are considered discriminatory of the minority groups. Che Mohd Aziz (2012) stated that the survival of the Southern Thailand Malay experienced challenges after the Thai Government used the assimilation approach in integrating the Southern Thailand Malay ethnic into the Thai society. The Thai government's misunderstanding towards the Southern Thailand Malay ethnic's culture has led to disrespect of other cultures. Most policies and approaches used are discriminatory in nature and did not respect the interests and rights of the Southern Thailand Malay ethnic minorities.

However, although it is apparent that the formation of the Southern Thailand Malay ethnic minority identity is influenced by the element of cohesion from the Government of Thailand (Che Mohd Aziz 2012; Imtiyaz 2009; May 2008; Che Man 2008; Kettani 2005; Walker, 2005; Ahmad Omar 2000; Suwannathat-Pian 2002), researchers viewed that at the same time, the willingness element from the Malay ethnic minorities of Southern Thailand also influences the formation of their identity. This is because the Malay ethnic minority of Southern Thailand are social beings who have needs and wants that must be fulfilled to adapt to the demands of life in line with the changing time and even more when the world became globalized. Time change has certainly demand changes in the needs and requirements of life. Therefore, the Southern Thailand Malay ethnic minority will also has the space and opportunities to benefit from the implementation of the coercive based government policy to suit to their needs and requirements in accordance with the current changes.

Therefore, this research is conducted by focusing the discussion on the experience of ethnic identity formation by the Southern Thailand Malay ethnic based on the colonial history, nation building, conflict and modernization. This study used the phenomenological approach focusing on the narration of the Southern Thailand Malay ethnic groups in Thesaban Takbai, Narathiwat on the ethnic identity formation experiences based on their world-view. The world-view is formed from the everyday language and daily routine in life. As a whole, this study aims to look at the identity built upon the current Southern Thailand Malay ethnic in Thesaban Takbai. Previous studies indicate that the process of the Southern Thailand Malay ethnic identity formation determined by the Thai Government's policy was resisted by the Southern Thailand Malay ethnic themselves. However, we cannot deny that time changes and modernization may influence and change the current perspectives of the Southern Thailand Malay ethnic on their identity, particularly for those who were not directly involved in the resistance against the Government of Thailand. The theoretical gap intended be explored in this study is about the clash between modernization and traditional in the process of ethnic identity formation that led to the conflict between the majority and minority groups.

Historical background shows that the modernization agenda brought about by the Government of Thailand to produce citizens of Thailand and to establish a national identity and a modern Thailand nation based on the Thai and Western mould has touched the sensitivity and traditions of the Southern Thailand Malay ethnic from the perspectives of religion, culture, language and education. The colonial history factor and the differences in ethnicity, religion, language and culture made it difficult for the Government of Thailand to implement a thorough modernization agenda on the Southern Thailand Malay ethnic. The Southern Thailand Malay ethnic resistance towards Thailand modernization either translated by violence conflicts or in the form of peaceful struggles are reflections of the efforts to maintain the traditional Malay ethnic identity of the Southern Thailand from the perspectives of religion, culture, language and education (Ahmad Omar 2008; Aphornsuvan 2004; Dorairajoo 2009; Walker 2005). The resistance is seen as being able to control and slow down the implementation of modernization towards the Southern Thailand Malay ethnic but is not able to fully prevent them to be involved in the Thailand modernization agenda. On the other hand, the situation has brought the Southern Thailand Malay ethnic to be involved in the clash between modernization and tradition in the process of identity formation, thus encouraging them to adapt for the sake of ethnic and life survival as Thailand citizen with the minority status. Therefore, the main focus of this study is to understand the type of language and cultural identity desired by the Malay ethnic of Thesaban Takbai, Southern Thailand.

\section{The Concept of Identity}

Identity are characteristics or distinctive properties that form the character, personality or character of each individual and group (Giddens 2008). Identity is a set of meanings and experiences that contain an explanation of who the individual or a group is in the self-view and in the eyes of other people (Giddens 2008; Castells 2004). Meanings and experiences were built into the elements of identity such as name, language, religion, culture and others. Meanings and experiences that serve to distinguish between the self and others, simultaneously give meaning to the existence of the self and others as described by Castells (2004): 
We know of no people without names, no languages or cultures in which some manner of distinction between self and other, we and they, are not made...self-knowledge - always a construction no matter how much it feels like a discovery - is never separable from claims to be known in specific ways by others.

Identity concept has a very broad scope of discussion in Sociology. Dictionary of Sociology (2009) states that there is no clear and permanent concept to explain on identity. It is used widely and loosely in reference to the meaning of one's sense of self as well as the ideas and one's feelings and ideas about oneself (Dictionary of Sociology 2009). Lee (2006), who conducted a study on the identity of Chinese in Malaysia states that not all studies of identity have meticulously described the definition of identity. The situation may have been caused by a very complicated process of conceptualizing the identity terminology. As the concept of identity is a concept that is broad and vague, therefore the categorization of identity is also influenced by it. There are various categories of identity presented by the identity researchers from various disciplines. In general, there are three main categories of identity that can be the fundamental in understanding the concept of identity in Sociology. The three categories are personal, ego and social identity.

The study of the Southern Thailand Malay ethnic identity focuses the discussions on the social identity. Social identity is a public realities resulting from the social processes defined by the groups in society (Hutnik 1991). George Herbert Mead's classic text of Mind, Self and Society emphasizes that social identity is created through the ongoing social interaction with others and form the self-reflections about "who we think we are" (Dictionary of Sociology, 2009). Mead's work shows that identity is produced through an agreement, disagreement and negotiations with others (Dictionary of Sociology 2009). The human behaviours and self-image adaptation will depend on their interactions. Selfreflection of this interaction is also named as looking glass self (Dictionary of Sociology 2009). Therefore, identity can be considered as something important because it gives meaning to the existence of the creation of the universe whether humans, things as well as substance (Jenkins 2004). As social beings, identities have multiple importance to the human because it is not only meaningful to the individual's human existence, but also creating the sense of belonging to the group, forming solidarity within the group and determine the form of social relations in the society as a whole.

\section{Background of the Study Area}

Thesaban Takbai is a ward (tambon). It is one of the eight wards found in Takbai District (amphoe) consisting of Phrai Wan, Phron, Sala Mai, Ban Khun Tong, Khosit, Kok Sathon and Na Nak Parish. Takbai District is located in the Narathiwat Province. In the Thai language, province is named as changwat, district as amphoe, ward as tambon, village as muban and town as thesaban. Thesaban Takbai or better known as Takbai is well known by a number of international communities because it is the location of the occurrence of Takbai Demonstration 2004 (see Figure 1). Prior to that, the issue of the Southern Thailand Malay ethnic was regarded as Thailand's domestic problem and received less attention from the international communities.

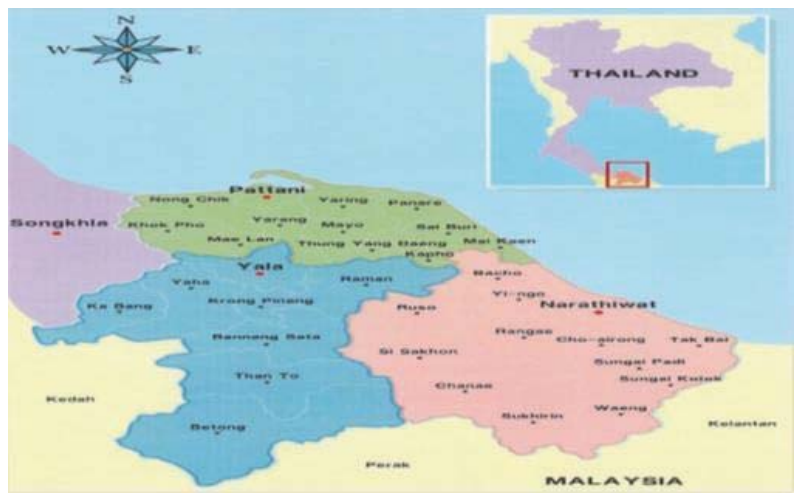

Figure 1: Location of Study

However, after the Takbai Demonstration in 2004 highlighting the actions that was deemed as discrimination against the Southern Thailand Malay ethnic by the Government of Thailand, the international communities began to look at the issue of the Southern Thailand Malay ethnic in the context of minority and majority relations. Thailand Government actions in 
addressing the event was condemned because it contain elements of human rights violation on the minority groups.

Despite the fact that the Southern Thailand Malay ethnic has long been confronted with acts of human rights violation, the actions previously were handled in the context of Thailand's province problem only. McCargo (2009) viewed that the isolation of the Southern Thailand Malay ethnic from the international knowledge may be due to the absence of foreign nationals who had been assaulted in the conflict.

\section{Research Methodology}

A phenomenological approach is used in this study. The phenomenological approach is an approach suggesting that an understanding of the social actor's reality of life is examined through the subjective experience of the social actors themselves including the standpoint, conscience and social actors' attitudes towards themselves and their world (Blaikie 2010). The main focus of this phenomenological study is to elaborate and describe the life experiences of the social actors which is still in the abstract form. Phenomenological approach in the social sciences has been integrated by Shutz. Shutz states that the object of social science's research is basically related to the interpretation of reality (Blaikie 2010). In this study, the primary data collected were derived entirely from the social actors through the natural part of the social environment. The data was collected using the in-depth interviews. The interview is unstructured. In-depth interviews was informally conducted through conversations and narrations to create a relaxing atmosphere. Indirectly, it creates comfort to the informants to talk freely and not bounded by formality. Therefore, the overall data in this study is qualitative textual data in nature.

The study population consists of the Southern Thailand Province Malay ethnic communities. While the sample of study or analysis unit consists of ten Southern Thailand Malay ethnic individuals living in Thesaban Takbai, Narathiwat, Thailand. The ten informants consists of five men and five women in the age range of $20 \mathrm{~s}$ to 60 s covering various employment and level of education backgrounds. Samples of study were selected based on the non-probability sampling using two sample selection techniques of purposive sampling and snow ball sampling. The transcript in Patani Malay language were written back into the standard Malay language as the second transcript to provide a better understanding of the study. The data were then analysed using NVivo software.

\section{Research Findings}

\subsection{Cultural Identity Desired by the Southern Thailand Thesaban Takbai Malay Ethnic}

During the initial implementation of the Thailand modernization, the clothing aspect became a very important issue because there is an instruction in the Rathaniyom Policy 1938 (Thai Cultural Policy), prohibiting people of Thailand from wearing clothes with traditional features. The Southern Thailand Malay ethnic were not allowed to wear clothes that reveal the traditional Malay culture like sarong (kain pelekat), baju kurung, turban, cap (kopiah) and hijab. The Southern Thailand Malay ethnic female students in the Primary and Secondary Thai Schools and the female workers in government offices were not allowed to wear the clothes that covers themselves according to their religion. However, the Rathaniyom Policy were abolished in 1944 due to the resistance from the Southern Thailand Malay ethnic. They were then allowed to dress-up according to the traditional Malay culture. The recent development shows that the Government of Thailand has allowed the female students in Thai Primary and Secondary Schools and universities and the female workers in government offices to wear their clothing according to the religion and clothing characterized by the Malay culture such as the traditional clothes (baju kurung). Similar to the issue of religious identity, the cultural identity issue is not a sensitive issue to the informants.

All informants state that they want to maintain the Malay culture in the way they dress-up and the name usage. The desire to maintain the Malay culture is totally dependent on their appreciation towards religion and loyalty towards the Malay culture. The Thai government no longer prohibit them to wear the traditional Malay culture characterized dressed. On the other hand, the challenges faced by the Southern Thailand Malay ethnic today in maintaining the elements of Malay tradition in the clothing aspect is the current challenges of globalization that come in the form of open socializing between Southern Thailand Malay ethnic with the Thai ethnic in schools, universities and cities; technological developments; the influence of social media and Thai celebrities; and the openness of parents in the children's' socialization process.. This matter was stated by Iza:

The Malay students studying in Bangkok were swayed by the Siamese cultural clothing (Thai). Many of the female students especially those studying in the Government Schools (Thai School) have started wearing modern clothing like 
jeans and t-shirt. When I was a teenager, no girl was wearing pants, but now it has existed. The dress issue among adolescents is also related to the way of upbringing by the parents. If the parents are less concerned about religion, the children's clothing will not follow the Malay culture and does not comply with the Islamic way. The Malays should maintain the Malay characterized clothing.

In conclusion, similar to the religious identity, the informants' desire to preserve the Malay cultural identity shows that the modernization brought about by the government through the development policy does not change the informants' cultural identity. Informants' desire to maintain the traditional Malay cultural identity in their clothing has retained informant's original identity as the Malay ethnic which was formed based on the Malay culture although informants have been exposed to the modernization that came through the naturally acquired knowledge, socializing and exposure to technology or others.

\title{
5.2 Language Identity Desired by the Southern Thailand Thesaban Takbai Malay Ethnic
}

The informants' views on the desired language identity reveal their tolerance towards the position of Thai language as the national language. All informants accepted the status of Thai language as the national language. They did not refuse the obligation to learn the Thai language in schools.

All informants can speak the Thai language because all of them were involved in the Thai education system at the primary level. In fact, all of the informants state that the obligation to learn Thai language provides advantage to the Southern Thailand Malay ethnic to master more than one language and enable them to interact with the Thai ethnic as described by Ahmad, Rubi and Iza:

\begin{abstract}
Ahmad: The Malays cannot refuse the use of Siamese language (Thai language) because as a citizen we must learn the Siamese language (Thai language) at school for 12 years. After all, it is nice to learn the Siamese language (Thai language) because we can master many languages and it facilitates us to interact with the Siamese (Thai people). Siamese language (Thai language) is difficult to learn. It is a waste if we as citizens cannot speak the Siamese language (Thai language).
\end{abstract}

Rubi: The Malays have no problem to use any languages. The government does not forbid us to speak using any languages. Just years before, the government had banned the use of other languages in schools, only the Siamese language (Thai) was allowed. But for me it is good to enable the students to master the Siamese language. The Malays must master the Siamese language (Thai) to prevent ourselves from being cheated by the Siamese (Thai).

Iza: For me, we learn Siamese language (Thai language) for the development of knowledge and improvement of language skills, there's nothing wrong in learning the Siamese language (Thai language) but not to forget the Malay language (Patani).

However, all of the informants state that their acceptance of the Thai language as the national language of Thailand that is compulsory in schools has not pushed aside the Patani Malay language as their mother tongue. They want the Patani Malay language to be continuously spoken by the Southern Thailand Malay ethnic as the main language among them. In other words, all the informants want the language identity among the Southern Thailand Malay ethnic to be characterized by the Patani Malay language as their mother tongue and Thai language as the national language. Indirectly, the informants' openness towards the responsibility of learning the Thai language and their desire to learn the language has formed their new identity in which they are no longer Patani Malay language centred but also the Thai language. The bilingual identity is the identity that will distinguish the Southern Thailand Thesaban Takbai Malay ethnic with the non-Malay Muslim in Thailand and also the Malay ethnic outside Thailand such as Malaysia.

\section{Research Conclusion}

The desired identity shows that the Southern Thailand Thesaban Takbai Malay ethnic is the minority Malay ethnic group who still adhere to the traditional identity of the religion (Islam) and culture (Malay) but are beginning to show tolerance towards the modernization in the language and education perspectives. They do not reject modernity but the modern and traditional elements that have been integrated into the education structure has given the Southern Thailand Thesaban Takbai Malay ethnic choices to balance between their desire to maintain the elements of religious tradition (Islamic Education) with the social mobility needs (academic education). Thus, the current identity formed on the Southern Thailand Thesaban Takbai Malay ethnic has been mixed with the modern elements but at the same time does not 
eliminate the traditional elements. In fact, the traditional elements are still dominating the Southern Thailand Thesaban Takbai Malay ethnic identity. The modern elements are acculturated for adaptation purposes as a minority group in Thailand and for the purpose of social mobility and does not change the original identity of the Southern Thailand Malay ethnic identity.

\section{Acknowledgement}

This study was supported by Universiti Kebangsaan Malaysia under the Research Financial Assistance BKBP-FSSKK014494-2014 and University Research Grant (GUP-2014-074) which has enabled this study to be conducted smoothly and successfully.

\section{References}

Ahmad Omar Chapakia. (2000). Politik Thai dan Masyarakat Islam di Selatan Thai. Alor Setar: Pustaka Darussalam.

Ahmad Omar Chapakia. (2008). Pembaharuan politik Selatan Thai dan perjuangan masyarakat Islam. DIm. Farid Mat Zain \& Zulkarnain Mohamed. (pnyt.). Muslim Selatan Thai, Konflik dan Perjuangan, hlm. 199-233. Shah Alam: Karisma Publications.

Aphornsuvan, T. (2004). Origins of Malay Muslim "separatism" in Southern Thailand. Asia Research Working Paper No. 32. Oktober 2004. http://www.ari.nus.edu [18 Mei 2013].

Blaikie, N. (2010). Designing Social Research. Edisi-2. United Kingdom: Polity Press.

Castell, M. (2004). The Power of Identity. Edisi ke-2. United Kingdom: Blackwell Publishing.

Che Man, W. K. (2008). Melayu Muslim Selatan Thai. Dlm. Farid Mat Zain \& Zulkarnain Mohamed. (pnyt.). Muslim Selatan Thai, Konflik dan Perjuangan, hlm. 3-30. Shah Alam: Karisma Publications.

Che Mohd Aziz Yaacob. (2012). Asimilasi bangsa Melayu di Patani: Keberkesanan dasar dan survival budaya minoriti. Jebat: Malaysian Journal of History, Politics \& Strategies Studies 39 (1): 97-123.

Dictionary of Sociology. (2009). Edisi ke-3. New York: Oxford University Press.

Dorairajoo, S. (2009). Peaceful Thai, violent Malay (Muslim): A case study of the 'problematic' Muslim citizens of Southern Thailand. Copenhagen Journal of Asian Studies 27(2): 61-83.

Giddens, A. (2008). Sociology. Cambridge: Polity Press.

Hutnik, N. (1991). Ethnic Minority Identity. New York: Oxford University Press.

Imtiyaz Yusof. (2009). Ethnoreligious and political dimensions of the Southern Thailand conflict. DIm. Pandya, A. \& Laipson, E. (pnyt.). Islam and Politics: Renewal and Resistance in The Muslim World, hIm. 43-120. Washington: The Henry L. Stimson Center.

Jenkins, R. (2004). Social Identity. Edisi ke-2. Canada: Routledge.

Kettani, M. A. (2005). Minoritas Muslim di Dunia Dewasa ini. Terj. Soejoeti, Z. Jakarta: Rajawali Pers.

Lee, Yok Fee. (2006). Identiti harian dalam subjektiviti orang Cina Malaysia. Tesis Dr. Fal, Jabatan Antropologi dan Sosiologi, Universiti Kebangsaan Malaysia.

May, R. J. (2008). Faktor agama dalam tiga gerakan minoriti Moro Filipina, Melayu Thai dan Papua Barat Indonesia. Dlm. Farid Mat Zain \& Zulkarnain Mohamed. (pnyt.). Muslim Selatan Thai, Konflik dan Perjuangan, hlm. 105-128. Shah Alam: Karisma Publications.

Suwannathat-Pian, K. (2002). Thailand: Historical and contemporary conditions of Muslim Thais. Dlm. Abdul Monir Yaacob \& Zainal Azam Abdul Rahman. (pnyt.). Muslim's Right in Non Muslim Majority Countries, hlm. 1-28. Kuala Lumpur: Penerbit Institut Kefahaman Islam Malaysia (IKIM).

Walker, D.P. (2005). Conflict between the Thai and Islamic cultures in Southern Thailand (Patani) 1948-2005. Jurnal Islamiyyat 27 (1): 81-117. 